\title{
ДОСЛІДЖЕННЯ ФАРБОВИХ АПАРАТІВ ОФСЕТНИХ ДРУКАРСЬКИХ МАШИН РОЗГАЛУЖЕНОГО ТИПУ
}

๑ Ю. О. Шостачук, к.Т.н., доцент, О. П. Шостачук, аспірант, НТУУ «КПІ», Київ, Україна

В статье рассматривается методика и результаты исследования разветвленных красочных аппаратов листовых офсетных печатных машин.

The article is devoted a design procedure of the branched out colourful devices of sheet offset printing machines.

\section{Постановка проблеми}

Ефективність друкарських машин офсетного друку і якість відтворення зображення у них залежить від якості розкочування та рівномірності нанесення шару фарби на друкарську форму і далі на відбиток і визначається наявною конструкцією фарбового апарату (ФА) та можливістю миттєвого корегування його параметрів налаштування [1].

Існуючі рекомендації щодо вибору типу ФА та методи ї розрахунку, особливо для розгалужених систем, досить ускладнені $[1,2]$. У кожного виробника друкарського обладнання $€$ свої оригінальні технічні рішення, які $€$ його інтелектуальною власністю, інформація про які у вільному доступі практично відсутня. Для подальшого удосконалення конструкції ФА необхідно мати доступні програмні методи 3 можливістю моделювання процесу нанесення фарби залежно від ї призначення та конструкції.

\section{Аналіз попередніх} досліджень

ФА офсетного способу друкування призначений для підготовки фарби з наданням їй певних характеристик та забезпечення стабільного нанесення їі по всій площі друкарської форми протягом всього часу друкування накладу. Крім того, ФА повинен забезпечувати безступінчасте зональне регулювання подачі фарби з мінімальним запізненням, а також постійний контроль за рухом фарби впродовж всього періоду виконання замовленння.

Фарби офсетного друку $€$ в'язкими $(1,4 \ldots 46$ Па.с) і потребують попередньої підготовки перед їх нанесенням на задруковуваний матеріал, що вимагає наявності у ФА для розкочування та формування рівномірного шару великої кількості (до 21) валів та циліндрів [1, 3].

Процес розкочування і формування шару фарби характеризується кількістю поданої та нанесеної фарби, ії властивостями, конструктивними особливо- 
стями ФА (кількістю та діаметрами валів і їх відносним розташуванням), шорсткістю задруковуваного матеріалу, мікрогеометрією друкарської форми і офсетного полотнища, а також визначається такими параметрами, як швидкість роботи, тиск в контактних зонах «валикциліндр», фізико-механічними властивостями еластичного матеріалу валів, величиною і частотою осьового розтиру, наявністю зволожуючого розчину на формі. Якість розкочування і накочування фарби і її розподіл залежать також від зміни внаслідок їх контакту температури поверхні фарбових валиків і циліндрів [3]. Надмірні температури у фарбовому апараті впливають на властивості фарби і призводять до зміни умов розкочування і переходу фарби з однієї поверхні на іншу та порушення балансу «фарба-волога».

Основними характеристиками ФА є коефіцієнти накопичення фарби Кн, розподілу фарби в зоні контакту двох тіл $\alpha$ і перенесення фарби на задруковуваний матеріал $\beta$, кількість і діаметри валів ФА, шорсткість поверхонь розкочувальних елементів, в'язкість фарби тощо. Спроби створити і описати «правильну» модель реального ФА ведуться давно [1-3]. На сьогодні не існує єдиних рекомендацій щодо вибору схеми ФА, кількості валиків в кожній з груп (дозувальній, розкочувальній, накочувальній), діаметрів валів і характеру їх розташування. Наявність багатьох факторів і різноманіття існуючих схем ФА потребує детального дослі- дження впливу всіх параметрів на процес підготовки і перенесення фарби. Існуючі методики розрахунку дозволяють за принципом додавання шарів і їх розподілу навпіл, складаючи послідовно ряд рівнянь для всіх контактних зон, вирахувати тільки середнє значення товщини фарбового шару на відбитку без визначення поведінки шару на валах $[1,2,4]$. Слід зауважити відсутність в публічному доступі загальнодоступних методів розрахунку та оптимізації конструкції ФА.

\section{Мета роботи}

Метою даної роботи є аналіз процесу перенесення фарби у ФА розгалуженої структури і розробка методики аналітичного дослідження параметрів ФА для оптимізації технологічного процесу розкочування фарби та конструкції фарбової групи.

\section{Результати проведених досліджень}

Процес підготовки фарби це розподіл поданої групою живлення порції фарби по поверхнях валів і циліндрів і надання фарбовому шару певних властивостей. Кінцевим результатом цього процесу $є$ накочування фарби рівномірним тонким шаром на друкарську форму. Розгалужена структура ФА підвищує ефективність розподілу і перенесення фарби, але ускладнює його дослідження. Для реального процесу 3 періодичною подачею фарби 3 використанням дуктора та передавального валу і з подальшим безперервним ії нанесенням на форму характерні

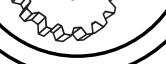

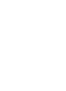


індивідуальне розщіплення фарби на окремих ділянках контакту при проходженні через валикові групи і відсутність точної методики опису реального процесу.

На практиці, коефіцієнт розподілу (а з ним і товщина фарбового шару) залежить від цілого ряду факторів, основними 3 яких $€$ :

- геометрія ФА (кількість валів, їх геометричні параметри і розташування);

- температура контактуючих поверхонь (підвищення температури зменшує величину шару фарби [3]);

- реологічні властивості фарби і наявність та вплив зволожуючого розчину;

- структура і якість матеріалів, чистота поверхні, прогин та точність балансування валів та циліндрів, наявність осьового переміщення валів;

- зворотній рельєф друкарських елементів, який утворюється на накочувальних валиках і передається на інші вали $\Phi A$.

Слід зауважити, що якість друку безпосередньо залежить від рівномірності нанесення на форму фарбового шару. Збільшення кількості валів у ФА підвищує стабільність шару, але вносить додаткові складності, пов'язані з визначенням розташування та геометрії конструкції, а також призводить до збільшення витрат фарби. Прямопотокова система подачі фарби характеризується мінімальною кількістю валів і, відповідно, мінімальним коефіцієнтом накопичення Кн, що не гарантує стабільності пара- метрів фарбового шару при виконанні складних завдань. Для підвищення ефективності ФА використовуються розгалужені системи, які характеризуються достатнім коефіцієнтом накопичення, але мають підвищену кількість валів і, відповідно, потребують своєї методики розрахунку.

Розглянемо подачу фарби розгалуженою системою при контакті трьох і більше валів і визначимо основні закономірності цього процесу.

Шар фарби після кожного контакту внаслідок розподілу між контактуючими площинами стає щораз тоншим. Це означає, що збільшення кількості валів і циліндрів між фарбоживильною групою і формою забезпечує стабільніший і тонший шар фарби на формі. Розгалуження загального потоку забезпечує накопичення додаткової кількості фарби, а також допомагає вирівняти мікронерівності, що виникають внаслідок зворотнього ефекту.

Дискретність подачі, вплив внутрішнього переміщення шарів фарби та різноманітність конструкцій ФА ускладнюють розрахунок таких розгалужених структур. Для створення моделі процесу розкочування і перенесення фарби у розгалужених фарбових групах використаємо принцип її розподілу з наступними припущеннями: шар фарби має однакову товщину на всій площі нанесення і змінюється внаслідок розподілу тільки у зоні контакту (відсутні втрати фарби у процесі передачі, наприклад, пилення, випаровування тощо). 
Такі спрощення дозволяють отримати упорядковану математичну модель для розрахунку фарбового шару на довільному валу системи, незалежно від кількості контактних зон і наявності розгалужень, пересікань і накладань потоків фарби та використати для її дослідження метод дискретних перетворень Лапласа. Враховуючи такі припущення, отримуємо систему рівнянь:

$$
\begin{gathered}
h_{i}=\alpha \cdot x_{i-1} \\
x_{i}=h_{i-1}+l_{i+1} \\
l_{i}=(1-\alpha) \cdot x_{i},
\end{gathered}
$$

де $\alpha$ - коефіцієнт позподілу фарби після контакту; $\mathrm{h}_{\mathrm{i}}(\mathrm{t}), \mathrm{x}_{\mathrm{i}}(\mathrm{t})$,
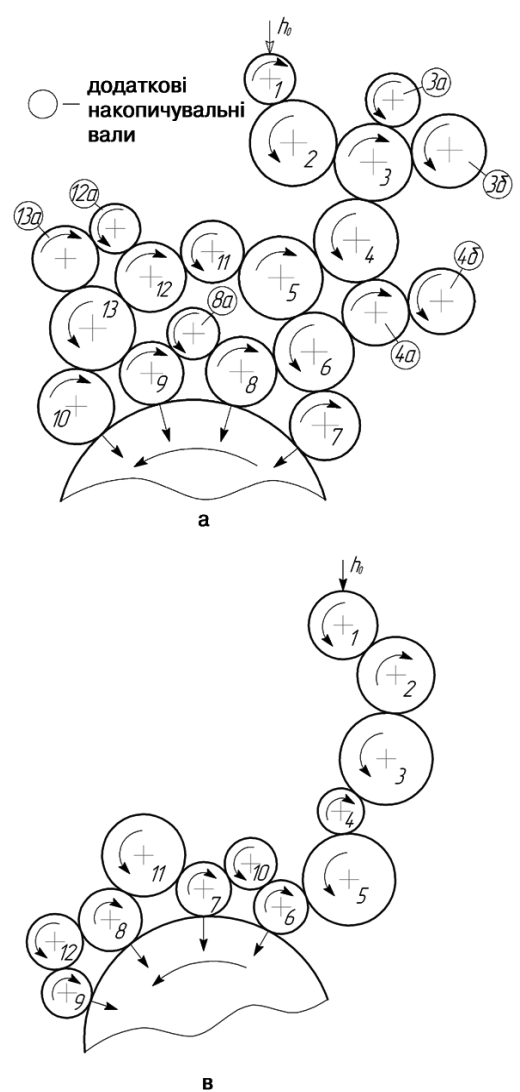

Рис. 1. Структурні схеми ФА офсетних листових друкарських машин:

a - Heidelberg «Speedmaster-102»; б - Heidelberg «XL 105»; B - KBA «Rapida 105»; r - MAN «Roland 700»

$\mathrm{l}_{\mathrm{i}}(\mathrm{t})$ - параметри зміни товщини шару фарби внаслідок контакту; $\mathrm{t}^{-1}$ - час обертання валів та циліндрів між контактами.

Залежності (1) дозволяють описувати системи ФА 3 довільним з'єднаннням валів. Приклади опису матриць наведені у роботі [3].

Для дослідження процесу розподілу і нанесення фарби на задруковуваний матеріал у розгалужених системах були складені структурні схеми ФА сучасних листових офсетних друкарських машин Heidelberg «Speedmaster-102» (рис. 1, a); Heidelberg «XL 105» (рис. 1, б);
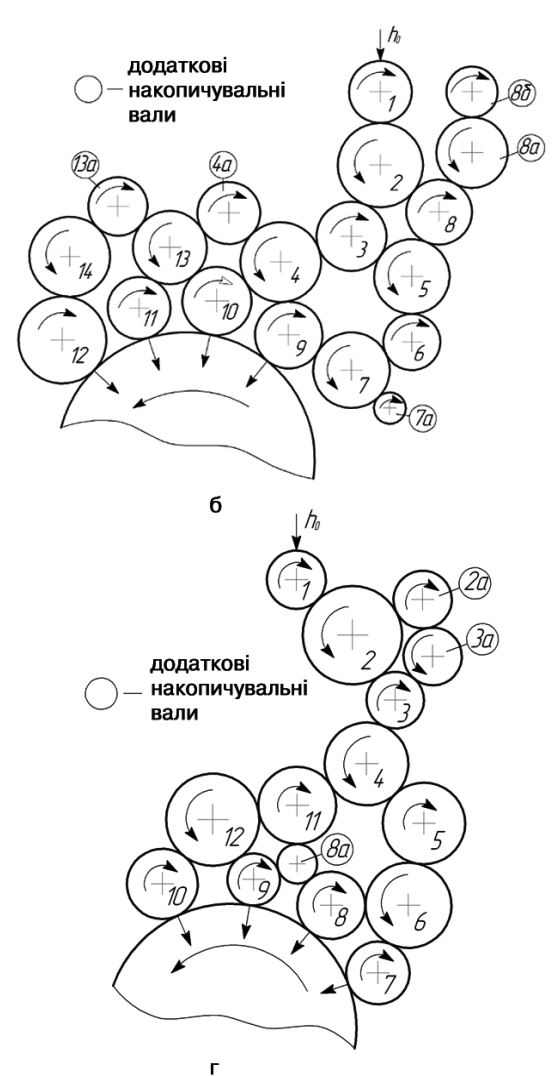

\section{:}


KBA «Rapida 105»(pиc. 1, в); MAN «Roland 700» (рис. 1, г), a також для порівняння - рулонних: офсетного газетного агрегату GOSS «Mainstream» (рис. 2, а) і машини акцидентного (журнального) друку Heidelberg «M 600» (рис. 2, б).

Приведені конструкції ФА характеризуються конфігурацією, розташуванням і характером взаємодії валів, діаметрами і матеріалом поверхонь валів, а також кількістю накочувальних валів. ФА (рис. 1, схеми а, в, г) мають дозуючу систему дискретного типу з подачею фарби з використанням коливного вала, ФА (рис. 1, схема б) - має систему дозованої подачі фарби з застосуванням камерракельного принципу, ФА (рис. 2, схеми а та б) - характеризуються безперервною подачею фарби з обмеженням подачі через наявність відповідного зазору між діаметрами дуктора та приймального валу.
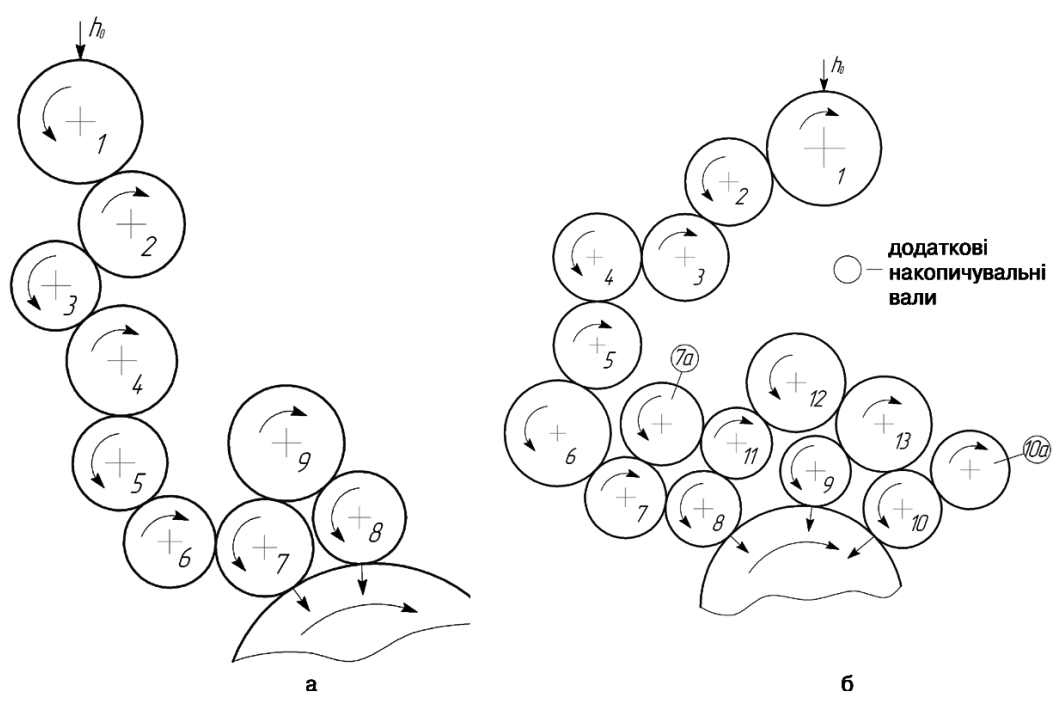

Рис. 2. Структурні схеми ФА офсетних рулонних друкарських машин:

a - GOSS «Mainstream»; б - Heidelberg «M 600»
Для дослідження і визначення величини шару фарби на валах ФА з розгалуженими потоками розроблена математична модель, в основу якої закладені залежності (1) і яка описується представленим нижче алгоритмом. Для зручності товщина шару фарби розглядається у відносному виді в умовних одиницях як відношення наявної товщини шару фарби на пошуковому валу ФА до необхідної товщини фарби на задруковуваному матеріалі $\left(\mathrm{h}_{0}-\right.$ товщина поданого шару фарби; $h_{1} \ldots h_{i}-$ фарбові шари відповідно на валах $1, \ldots i ; h_{c}$ - товщина нанесеного на задруковуваний ма-

На рис. 3 графічно представлені результати моделювання процесу розподілу фарбових шарів у фарбовій групі на прикладі ФА машини Heidelberg «Speedmaster-102» (див. рис. 1, а), де основний потік фарби теріал фарбового шару). 


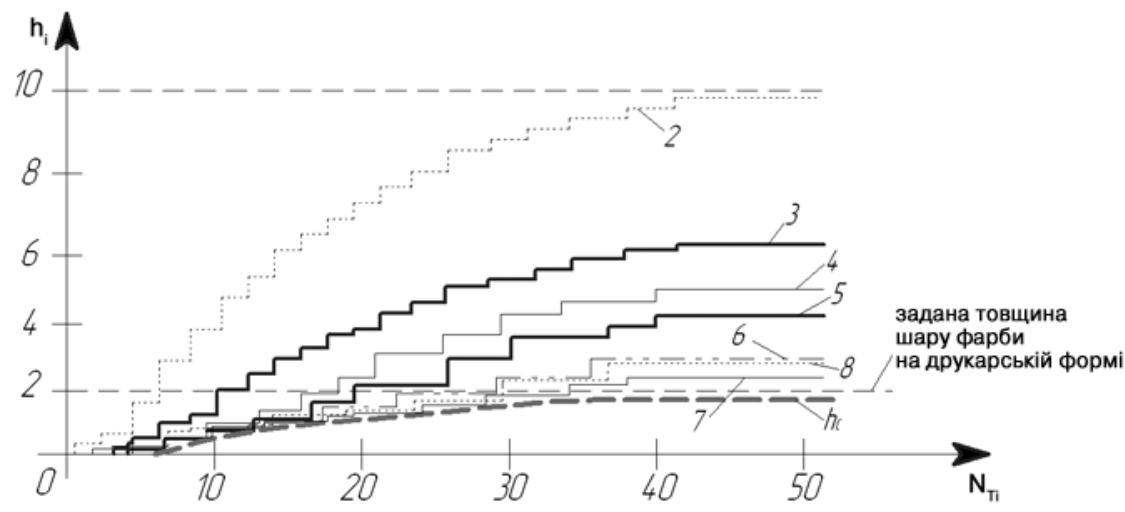

Рис. 3. Величини фарбового шару на відповідних валах ФА SM 102 (рис. 1, а; прийняті величини для розрахунку $\alpha=0,5 ; \beta=0,5$; номер кривої відповідає номеру вала)

відбувається через систему валів 2, 3, 4, 5 та 6 і які, для збільшення накопичення фарби і забезпечення стабільності товщини фарбового шару, який наноситься на друкарську форму накочувальними валами 7 і 8, контактують із супутниковими валами (в літературі інколи зустрічається назва - вантажні вали або вали-наїздники) За і Зб та 4a і 4б. Розгалуження відбувається від п'ятого вала, який разом із валами 11, 12, 13 і супутниковими валиками 12a і 13a утворює потужну розгалужену систему для розкочування та створення стабільного шару фарби на валах накочувальної групи 7-10.

Результати дослідження величини фарбового шару на супутникових валах 3а і Зб та 4 a i 4б, які приставлені відповідно до валів 3 та 4, приведені на рис. 4. Дослідження проводились при прийнятих величинах розподілу фарби $\alpha=0,5$ та $\beta=$ 0,5 . При цьому встановлено, що наявність додаткових валів зменшує реактивність ФА, але, внаслідок накопичення на них додаткової певної кількості фарби, суттєво підвищує стабільність товщини шару фарби на передавальних та накочувальних валах системи. Якщо розгалуження відбувається безпосередньо перед накочувальною групою, то спостерігається локальне збільшення шару фарби на накочувальних валах, що дозволяє мінімізувати коливання товщини шару фарби на формі, але призводить до зайвого накопичення фарби на валах і швидкого забруднення форми. Більш рівномірний розподіл фарби на поверхнях валів системи і прискорення процесу його стабілізації на формі відбувається при розгалуженості системи на ранній стадії. У ФА (рис. 1, а) для цього використані додаткові накопичувальні вали 12 a і 13а, які через вали 12 і 13 накопичують фарбу і, таким чином, запобігають ії передозуванню на накочувальних валах 9 і 10, що стабілізує утворення ос- 

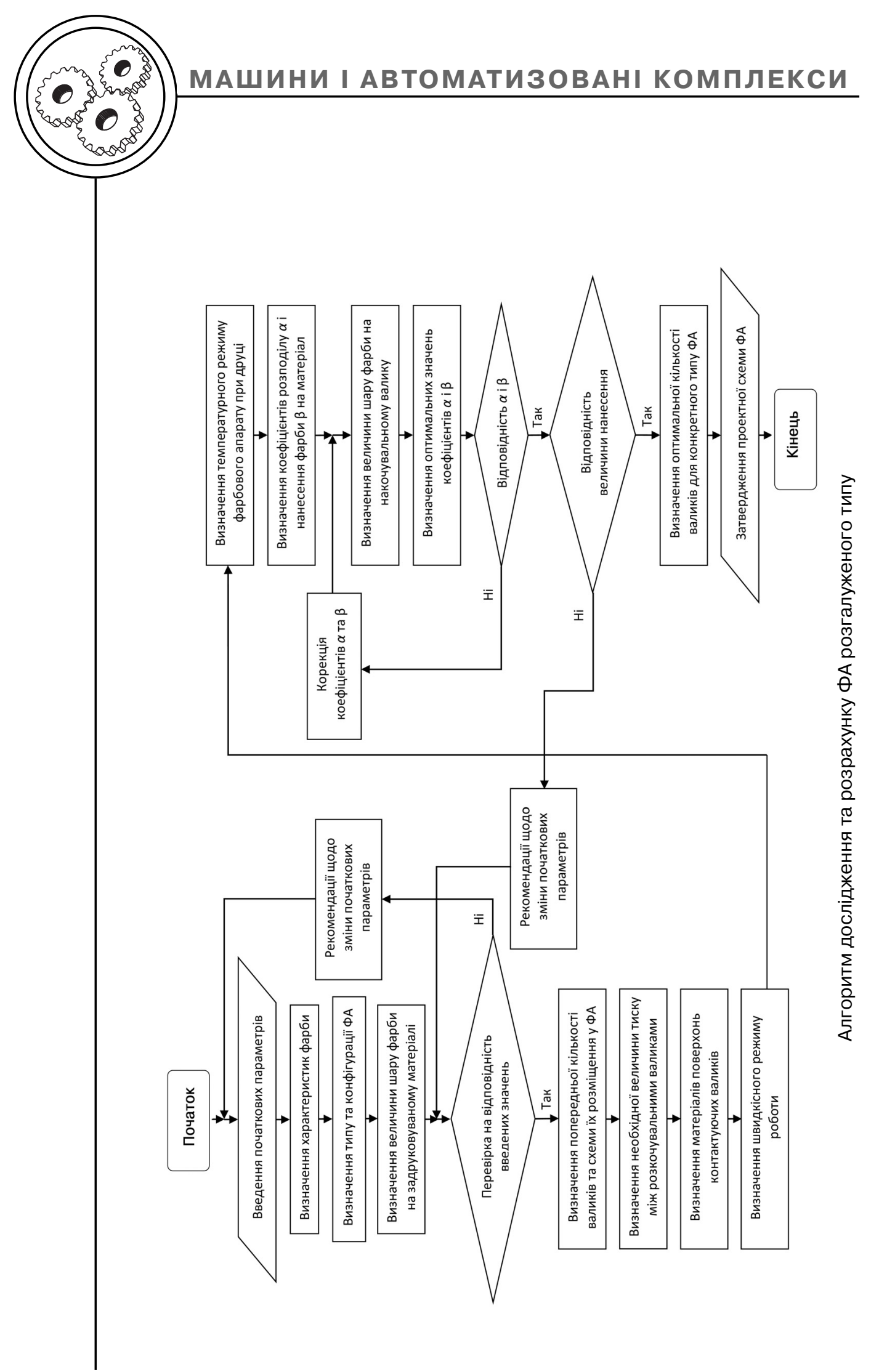

82 


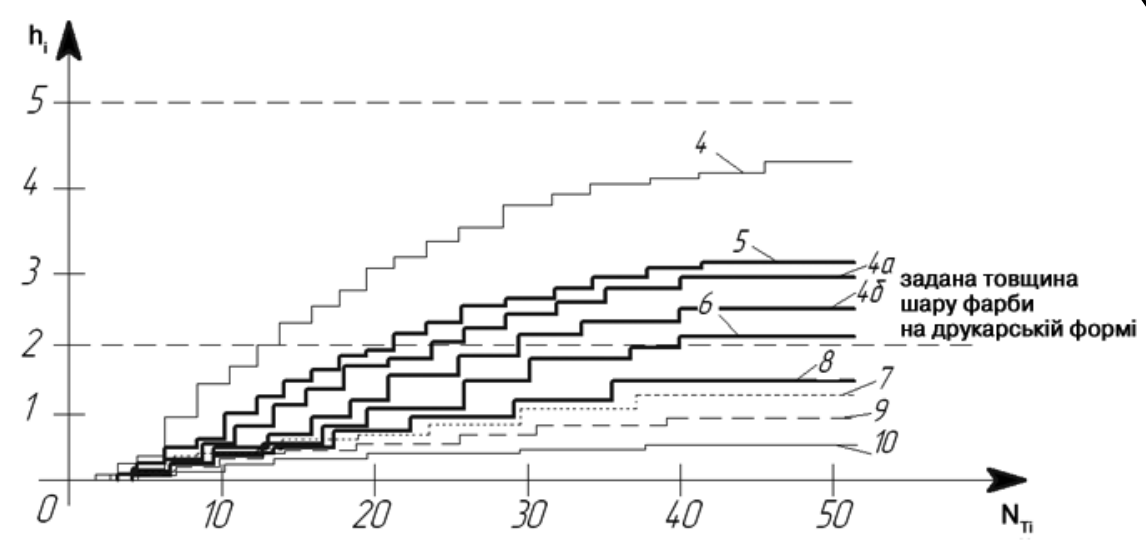

Рис. 4. Величини фарбового шару на накочу вальних валах розгалуженої фарбової групи ФА SM 102 внаслідок наявності супутникових валів 4а і 4б, 12a і 13a (рис. 1 , а, $\alpha=0,5 ; \beta=0,5 ;$ крива відповідає номеру валу)

таточного фарбового шару на друкарській формі (рис. 4). У ФА (рис. 1, г) для стабілізації фарбового шару використовуються додаткові накопичувальні вали $2 а$ та За. У ФА (рис. 2, б) для цього встановлені вали 7a, 10a (рис. 5).

На рис. 6 представлені результати моделювання процесу розкочування та перенесення фарби у ФА машини Heidelberg XL 105» (рис. 1, б). Безпосеред- ня подача фарби на накочувальну групу валів відбувається внаслідок контакту валів 1-4.

3 валами 2 та 3 зв'язана додаткова система валів 5 та 8 . 3 наведених графіків видно, що на валах 2 та 3 накопичується більша кількість фарби. Це пояснюється тим, що з валами 2 і 3 контактують вали 8, 8а і 8б, які у процесі розкочування набирають на себе, зберігають i поступово віддають у разі не-

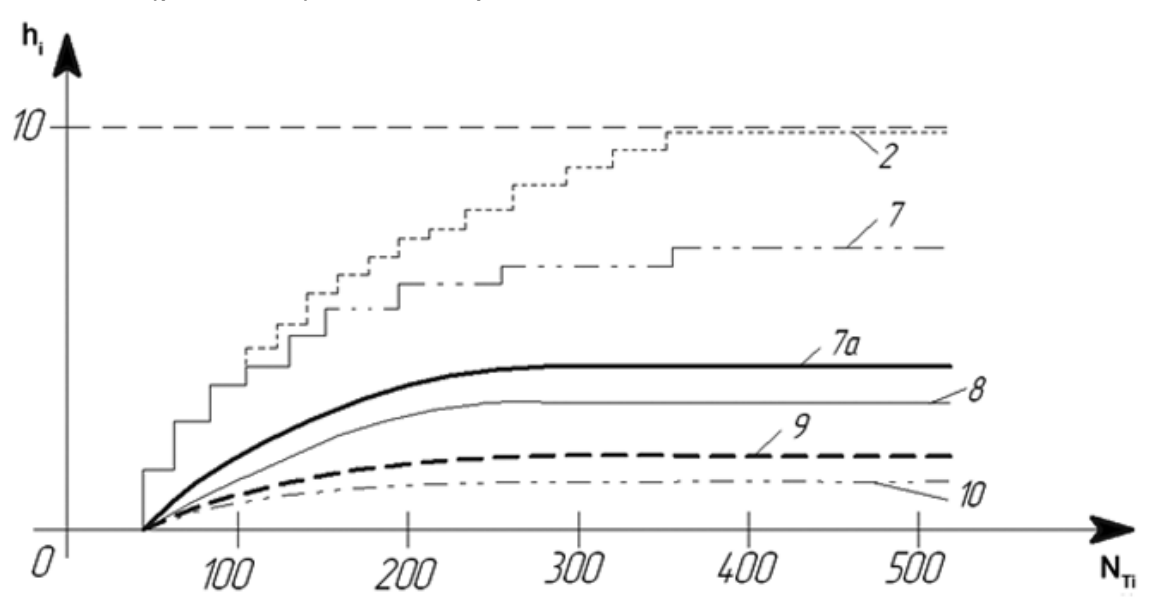

Рис. 5. Величини фарбового шару на валах ФА офсетної рулонної друкарської машини Heidelberg «M 600» (рис. 2, б, $\alpha=0,5 ; \beta=0,5$; позначення кривих відповідають номеру вала) 


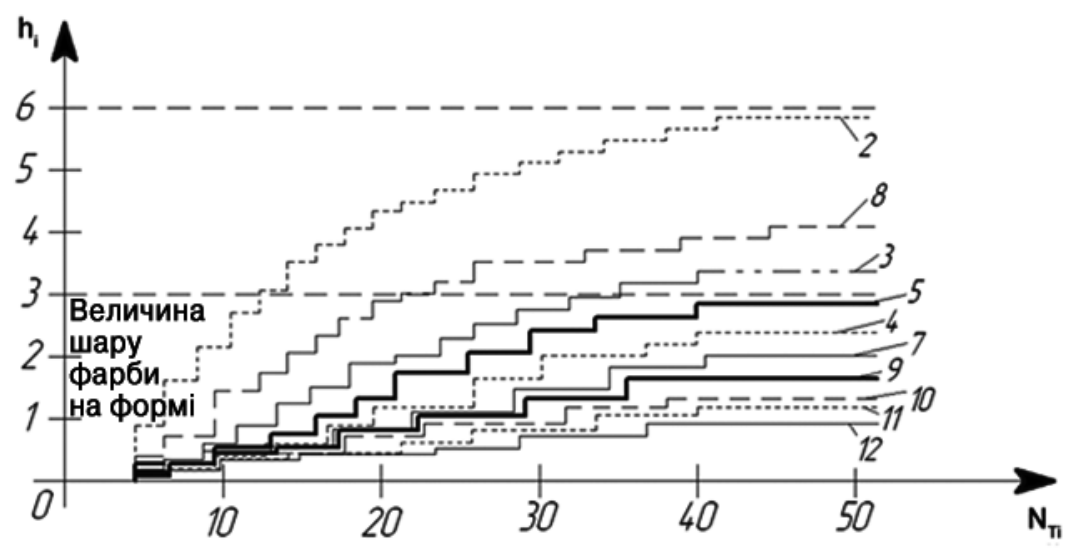

Рис. 6. Величини фарбового шару на валах ФА машини «Heidelberg XL 105» (рис. 1, б; $\alpha=0,5 ; \beta=0,5$; номер кривої відповідає номеру валу)

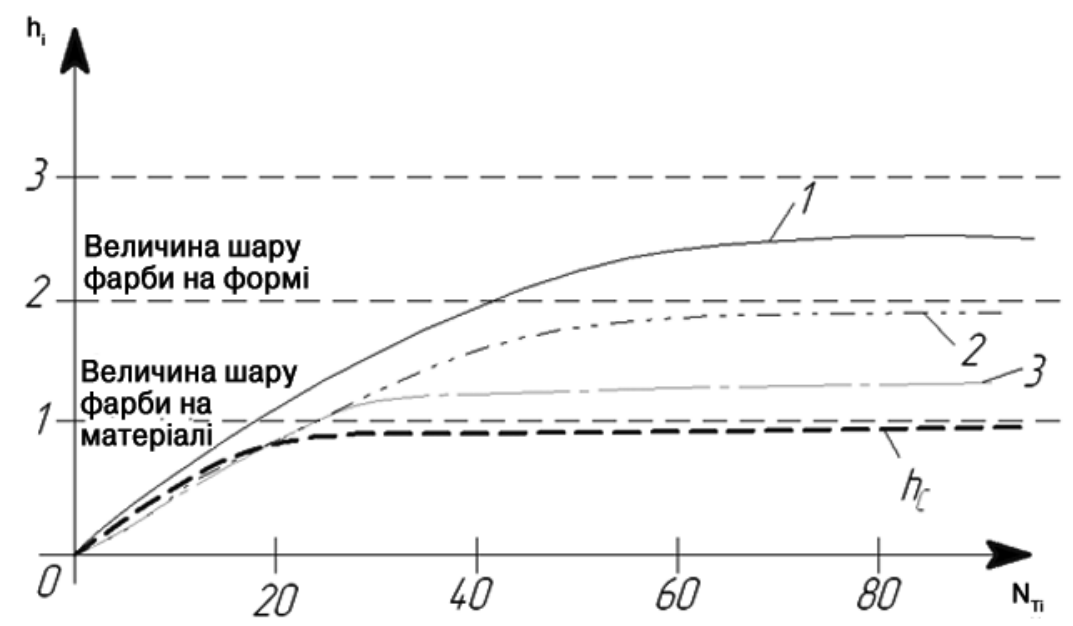

Рис. 7. Розподіл фарбового шару на валах ФА машини «Heidelberg XL 105» при роботі всіх та частково відключених груп (1 - максимальне підключення всіх валів - подача фарби через накочувальні вали 9-12; 2 - відведена перша група - подача фарби через накочувальні вали 9-11; 3 - відведено дві групи - подача через накочувальні вали 9-10)

обхідності зайву кількість фарби. Наявність додаткових вантажних валів 8, 8а та 8б, а також 7а забезпечує стабілізацію подачі необхідної кількості фарби на накочувальні вали 9-10.

Дослідження показали, що мультифункціональний ФА машини «Heidelberg XL 105» дозволяє регулювати кількість розко- чувальної та нанесеної фарби на відбиток залежно від складності сюжету. Це обумовлено дозуючою системою, а також можливістю змінювати структуру ФА за рахунок підключення або виведення 3 контакту певної кількості валів, що покращуе якість друку і оптимізує використання фарби (рис. 7). 


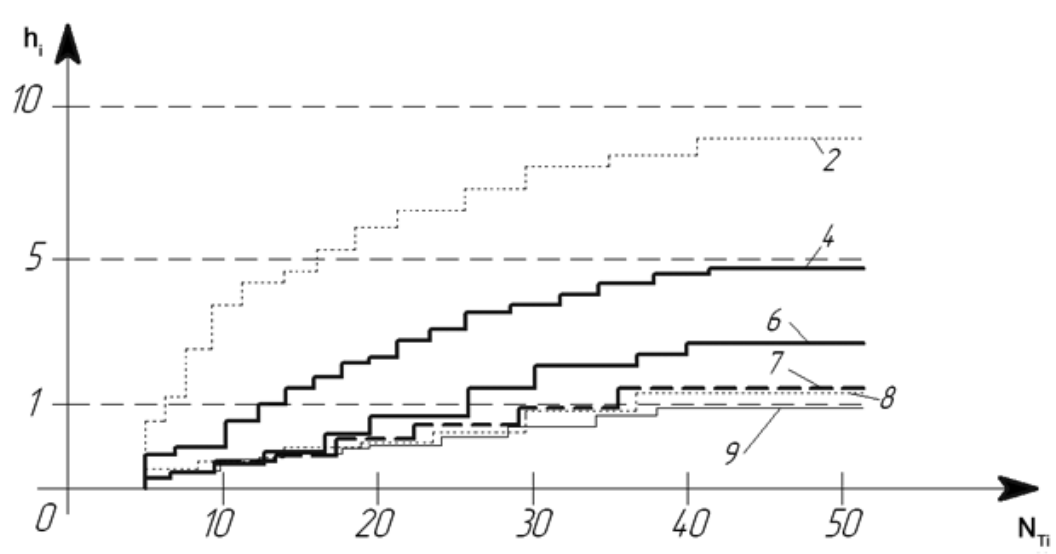

Рис. 8. Величини фарбового шару навалах ФА KBA Rapida 105 (рис. 1 , в; $\alpha=0,5 ; \beta=0,5 ;$ номер кривої відповідає номеру валу)

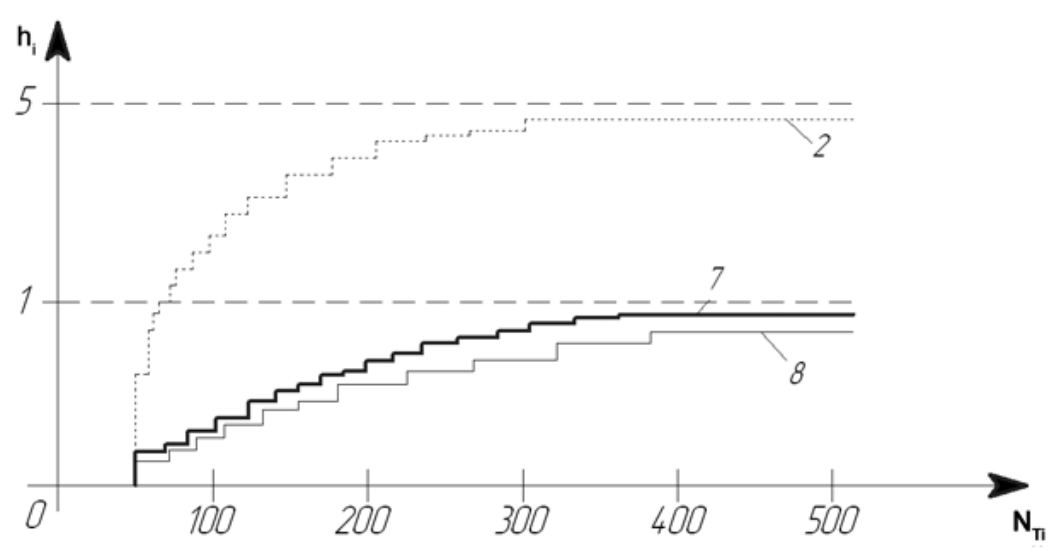

Рис. 9. Величини фарбового шару на валах ФА газетного агрегату GOSS «Mainstream» (рис. 2, a, $\alpha=0,5 ; \beta=0,5$; номер кривої відповідає номеру валу)

Для порівняння проведено аналіз ФА машини «KBA Rapida 105» (рис. 1, в) та газетного агрегату GOSS «Mainstream» (рис. 2, б), які характеризуються прямопотоковою системою подачі фарби. Це дозволяє швидко вийти на процес друкування, але для забезпечення стабільності нанесення фарбового шару, особливо при вико- нанні складних плашечних робіт, необхідно подавати підвищену кількість фарби (рис. 8, 9).

\section{Висновки}

В роботі запропонована математична модель процесу формування фарбового шару на будь-якому валику чи циліндрі i розроблено алгоритм аналізу ФА листових офсетних друкарських машин. Наведені ре- 
зультати дослідження процесу формування фарбового шару на валах сучасних ФА з використанням математичного апарату. Комп'ютерне моделювання процесу розподілу фарби таких систем 3 врахуванням конструкції, характеристик фарби та матеріалів контактуючих поверхонь дозволяє за допомогою відповідних програмних середовищ розглянути вплив практично всіх складових цього процесу.

Аналіз наведених результатів дозволяє зробити наступні висновки:

- розподіл фарбових шарів залежить від кількості розкочувальних елементів і контактних зон та коефіцієнта $\alpha$, який, у свою чергу, залежить від співвідношення діаметрів та розташування валів, матеріалів поверхонь, їх шорсткості та якості обробки;

- при зменшених коефіцієнтах розподілу $(\alpha<0,5)$ фарба накопичується у збіль- шених кількостях на перших валах фарбової групи, що дестабілізує процес розподілу; вирівнювання товщини шару фарби на валах та стабільність розкочування забезпечується при $\alpha \geq 0,5$;

- вплив на процес розподілу та швидкість підготовки фарби можна корегувати шляхом зміни шорсткості поверхні та співвідношення діаметрів контактуючих валів та їх температури, а також використовуючи супутникові вали, на яких додатково накопичується необхідна для подальшої стабілізації та рівномірного у випадку необхідності нанесення кількість фарби, внаслідок чого суттєво поліпшується якість друкованих відбитків. Коригування кількості валів у ФА дозволяє також зменшити витрати фарби (зменшуються також втрати фарби при змиванні ФА) і час, необхідний для підготовки та налаштування ФА до друку.

1. Шостачук Ю. О. Дослідження процесу розподілу фарбових шарів у фарбових апаратах друкарських машин / Ю. О. Шостачук, І. С. Жеребко, О. П. Шостачук // Техніка і технологія. - 2011. - № 1(31). - С. 88-99. 2. Rech H. Moegichkeiten und Grenzen der rechnergestuetzten Analyse von Offsetfarbwerken.Teil I bis IV. Druck-print 8, 9, 10, 11, 1984. 3. Щесюк T. A. Математичне моделювання процесу розкочування фарби в друкарських машинах : автореф. дис. на здобуття наукового ступеня канд. техн. наук : спец. 05.02.15. «Машини, агрегати і процеси поліграфічного виробництва» / Т. А. Щесюк. - Львів, УАД, 2000. - 20 с. 4. Broetz H., Hars Chr. Farbspaltungszahl im Nass-Offset-Farbwerk unter Einfluss des Feuchtmittels. TH Darmstadt, 1996. - 275 s. 
1. Shostachuk lu. O. Doslidzhennia protsesu rozpodilu farbovykh shariv u farbovykh aparatakh drukarskykh mashyn / lu. O. Shostachuk, I. S. Zherebko, O. P. Shostachuk // Tekhnika i tekhnolohiia. - 2011. - № 1(31). - S. 88-99. 2. Rech $\mathrm{H}$. Moegichkeiten und Grenzen der rechnergestuetzten Analyse von Offsetfarbwerken. Teil I bis IV. Druck-print 8, 9, 10, 11, 1984. 3. Shchesiuk T. A. Matematychne modeliuvannia protsesu rozkochuvannia farby $v$ drukarskykh mashynakh : avtoref. dys. na zdobuttia naukovoho stupenia kand. tekhn. nauk : spets. 05.02.15. «Mashyny, ahrehaty i protsesy polihrafichnoho vyrobnytstva» / T. A. Shchesiuk. - Lviv, UAD, 2000. - 20 s. 4. Broetz H., Hars Chr. Farbspaltungszahl im Nass-Offset-Farbwerk unter Einfluss des Feuchtmittels. TH Darmstadt, 1996. - 275 s.

Рецензент - О. В. Зоренко, к.т.Н., доцент, НТУУ «КП|»

Надійшла до редакції 27.02.13 